\title{
CEREBRAL CORTEX DAMAGE INDUCED BY ACUTE ORAL ALCOHOL INTAKE IS ASSOCIATED WITH OXIDATIVE STRESS IN WISTAR RATS (Rattus Norvegicus) \\ Eweoya Olugbenga Olawalea, Ayuba Lolo Shunomb ${ }^{b}$ Ajayi Abayomic*
}

a. Department of Anatomical Sciences, University of Abuja, Nigeria.

b. Department of Anatomy, Bingham University, Karu, Nigeria.

c. Department of Anatomy, Kogi State Nigeria.

*Correspondence to Abayomi Ajayi Department of Anatomy, Kogi State University Anyigba, PMB 1008, Anyigba, Nigeria. abajayi2003@yahoo.com

\begin{abstract}
The prefrontal cortex undergoes functional and structural changes due to binge or chronic alcohol consumption. This study examines alcohol-induced cerebral cortex damage and the association with oxidative stress in an animal model. Twenty-four Wistar rats (12 males and 12 females) weighing $150 \mathrm{~g}$ to $250 \mathrm{~g}$ were divided into four groups, A, B, C and D according to their weights. The rats in groups $B, C$ and $D$ were administered with $2 \mathrm{mls}$ of $52.5 \%, 16.5 \%$ and $4.3 \% \mathrm{v} / \mathrm{v}$ aqueous alcoholic solution respectively for 21 days. While rats in group A (control group) were given distilled water only, for the same period. The brain of each rat was excised, weighed and fixed in $10 \%$ formal saline for histological analysis while others were immersed in ice cold $30 \%$ sucrose solution, homogenized and analyzed for superoxide dismutase, malondialdehyde and acetylcholinesterase activity. Results indicate chromatolysis of Nissl bodies, cortical necrosis, and uneven neuronal loss with varying range of vacuolations in the prefrontal cortices of the alcohol treated rats in a dosedependent manner when compared with the control group. Cerebral cortex damage due to acute oral alcohol intake is associated with oxidative stress.
\end{abstract}

Keywords: Brain, cerebral cortex, alcohol, Wistar rats, oxidative stress

\section{INTRODUCTION}

The prefrontal cortex is a collection of interconnected neocortical areas that sends and receives projections from virtually all corticosensory systems, motor systems, and many subcortical structures. It occupies the anterior portion of the frontal lobes and is thought to be one of the most complex anatomical and functional structures of the mammalian brain. Its major role is to integrate and interpret inputs from cortical and sub-cortical structures and use this information to develop purposeful responses that reflect both present and future circumstances. This includes both actionoriented sequences involved in obtaining rewards and inhibition of behaviours that pose undue risk or harm to the individual (Miller \& Cohen, 2001).

Given the central role in initiating and regulating often complex cognitive and behavioral responses, it is no surprise that alcohol has profound effects on the function of the prefrontal cortex (Abernathy et al., 2010; Ahola et al., 2006). Chronic use of alcohol has been widely acknowledged to cause serious neurological and mental disorders, in the form of organic brain damage, memory loss, sleep disorders and psychosis, with or without seizures (Lee et al., 1979). The deleterious effects of alcohol are so many, thus understanding the structural damages caused by alcohol on the cerebral cortex and the concentrations at which alcohol induces such damages are very important. Moreover, the mechanisms by which alcohol produces its mood-altering and behavioural effects are still poorly understood. Hence, this research work is aimed at studying morphological changes in the prefrontal cortex caused by acute oral intake of alcohol and to understand the putative role of oxidative stress in alcohol-induced cortical damage in Wistar rats.

Submitted $10^{\text {th }}$ August 2017, Corrected $20^{\text {th }}$ January 2018. Published online $28^{\text {th }}$ February 2018. To cite: Olawale EO, Shunom AL, Abayomi A. 2018. Cerebral cortex damage induced by acute oral alcohol intake is associated with oxidative stress in wistar rats (rattus norvegicus). Anatomy Journal of Africa. 7: $1113-1120$. 


\section{MATERIALS AND METHODS}

\section{Animals}

Twenty-four (24) adult Wistar rats, twelve (12) males and twelve (12) females, weighing between $130-260 \mathrm{~g}$, were procured from National Veterinary Research Institute (NVRI) Vom, Plateau State, Nigeria. They were kept under standard conditions; maintained at $35.5^{\circ} \mathrm{C}-37.0^{\circ} \mathrm{C}$ ambient temperature and 12:12 hours light and dark cycle respectively in well ventilated cages cushioned with treated saw dust in the animal house of Bingham University, Karu, Nassarawa State, Nigeria and allowed to acclimatize for 2weeks before the start of the experiment. Males were separated from females to prevent mating. Rat feed (vital feed) obtained from Auta and water was given ad libitum.

\section{Animal Grouping}

Rats were divided into four (4) groups; A, B, $C$ and $D$ according to their weights, with 3 males and 3 females per group. Group A rats served as the control group.

\section{Preparation of Alcohol}

Pharmaceutical ethanol (94\%) (Loba Chemie Laboratory Reagents and Fine Chemicals, Mumbai, India) was diluted to give three (3) concentrations of alcohol. 4.3\%, $16.5 \%$ and $52.5 \% \mathrm{v} / \mathrm{v}$ aqueous alcohol solutions were prepared based on varying average body weights of rats.

\section{Experimental design}

As shown in Table $1,2 \mathrm{ml}$ of alcohol of the various concentrations and distilled water was administered orally to experimental rats according to their individual groups. Administration was done every morning for a period of 21 days using a $2 \mathrm{ml}$ syringe with an oral cannula at the tip. At the end of the experiment, animals' hearts were perfused with normal saline and formal saline, sacrificed through cervical dislocation and the brain dissected out, weighted and fixed immediately in $10 \%$ formal saline for histological analysis, while other brain tissues were immersed in ice cold $30 \%$ sucrose solution for biochemical analysis. All brain samples were stored in specimen bottles. Animals were weighed on the first and last day of the experiment.

\section{Histological Analysis}

Fixed brain tissues were dehydrated in ascending concentration of alcohol, cleared in two changes of xylene and embedded in molten paraffin. Sections of $5 \mu \mathrm{m}$ thickness were cut using rotary microtome and mounted on slides. Sections were then deparaffinised by passing through three changes of Xylene, rehydrated by passing through descending concentration of alcohol and then stained with hematoxylin and eosin (H\&E). Images of stained microscopic sections were thereafter taken under a light microscope.

\section{Biochemical Analysis}

Brain tissue samples were collected and immersed in ice cold $30 \%$ sucrose solution in specimen bottles. Samples were then homogenized and analyzed for sodium dismutase, malondialdehyde, total protein and acetylcholinesterase levels in the brain tissue. Acetylcholinesterase level was measured by photometric method following the method described by Ellman et al. (1961). The determination of sodium dismutase and malondialdehyde activities was done using the spectrophotometric assay by McCord \& Fridovich (1969) and Weitner et al., (2016) respectively. Total protein was determined using the biuret method.

Table 1: Groups of animals used in the study

\begin{tabular}{|l|l|l|}
\hline GROUPS & \multicolumn{1}{|c|}{ DOSAGE } & DURATION \\
\hline $\mathrm{A}$ & $2 \mathrm{ml}$ of distilled water & 21 days \\
\hline $\mathrm{B}$ & $2 \mathrm{ml}$ of $4.3 \% \mathrm{v} / \mathrm{v}$ aqueous alcohol solution & 21 days \\
\hline $\mathrm{C}$ & $2 \mathrm{ml}$ of $16.5 \% \mathrm{v} / \mathrm{v}$ aqueous alcohol solution & 21 days \\
\hline $\mathrm{D}$ & $2 \mathrm{ml}$ of $52.5 \% \mathrm{v} / \mathrm{v}$ aqueous alcohol solution & 21 days \\
\hline
\end{tabular}




\section{RESULTS}

The result shows whole and healthy neurons with very minimal distortion of the layer of prefrontal cortices in the control group (Figure 1) while the treatment groups ( $B, C$ and $D)$ showed increasing prefrontal cortical damage respectively (Figure 2 - 4). Group D showed the most damage with significant distortion of layer, presence of necrotic cells, apoptotic cells, cell vacuolation with nuclei moved to the side and loss of cell bodies (Figure 4). Cresyl fast violet staining of the brain sections also reveals whole and healthy neurons with a lot of Nissl bodies in the control group while the treatment groups $C$ and $D$ showed very little Nissl bodies, with group D showing a lot of necrotic cells with no high level of chromatolysis (Figure $3 \& 4$ ). Group B has some cells having little Nissl granules and some with a high concentration of Nissl bodies which may be indicative of DNA activity for protein production to cause repair (Figure 2).

There is a dose-dependent increase in the levels of sodium dismutase, malondialdehyde and acetylcholinesterase which is a mark of oxidative stress while total protein decreased at $p<0.05$ in the treatment groups as shown in Table 2.

The average body weights of rats in the control group increased by about $36 \mathrm{~g}$, while that of groups B, C and D reduced by $3 \mathrm{~g}, 8 \mathrm{~g}$ and $13 \mathrm{~g}$ respectively. This shows that an increase in concentration of alcohol consumed resulted in increased loss of weight. There was a significance of change of weight at $(p<0.05)$ compared to the control. There was however no significant difference in brain weights of groups B, C and D compared to the control group.
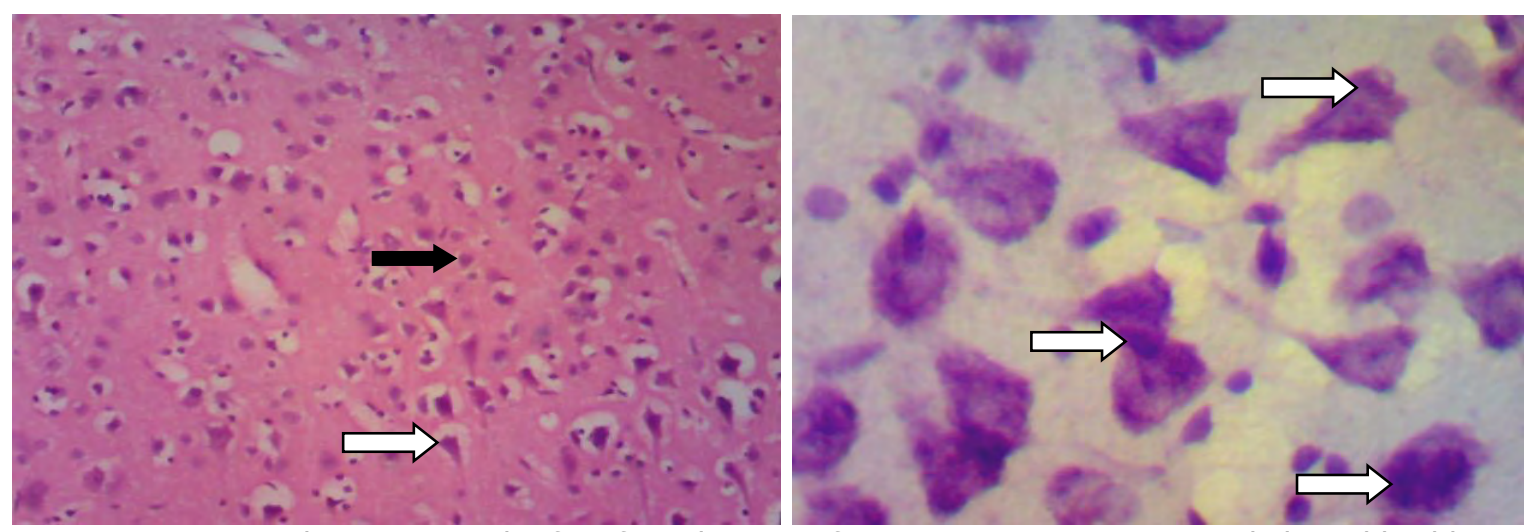

Figure 1: Group A: Photomicrograph of prefrontal cortex of group A rats. Neurons are whole and healthy with axons and dendrites (white arrow). There is minimal distortion (black arrow). H\&E X100. Group A: Photomicrograph of prefrontal cortex of group A rats. White arrows show Nissl bodies (granules). Cresyl Fast Violet Stain X400

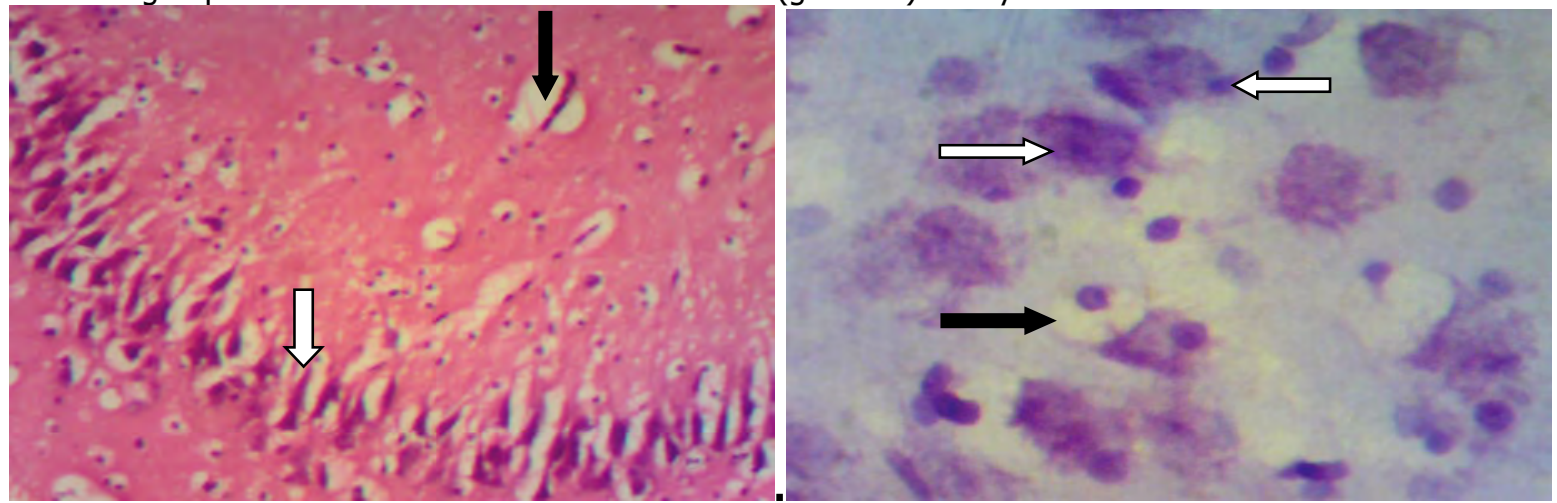

Figure 2: Group B: Photomicrograph of prefrontal cortex of group B rats. White arrow shows whole healthy neurons with axons and dendrites. Black arrow shows some distortion. H\&E X100. Group B: Photomicrograph of prefrontal cortex of group $B$ rats. White arrow shows nissl bodies. Black arrow shows a necrotic cell. Cresyl Fast Violet Stain X400 

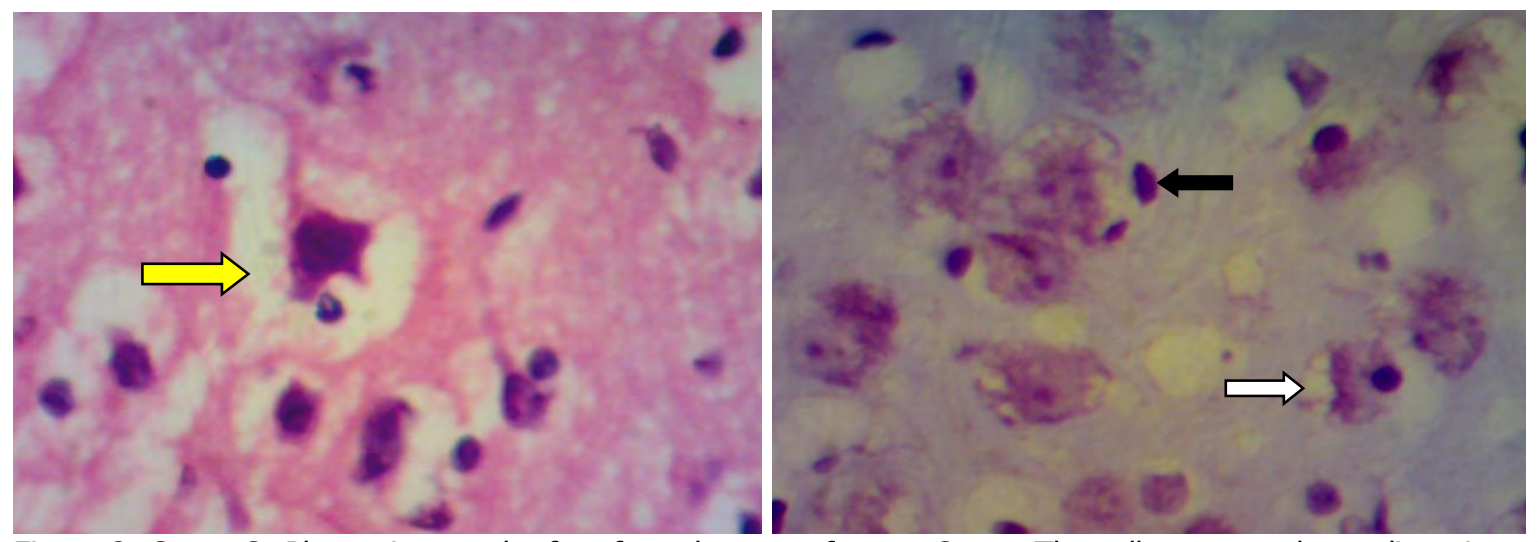

Figure 3: Group C: Photomicrograph of prefrontal cortex of group C rats. The yellow arrow shows distortion of the cortical layer. H\&E X400. Group C: Photomicrograph of group C rats. White arrow shows vacuolation with nucleus pushed to the side. Black arrow shows necrotic cells. There are few Nissl bodies. Cresyl Fast Violet Stain X400

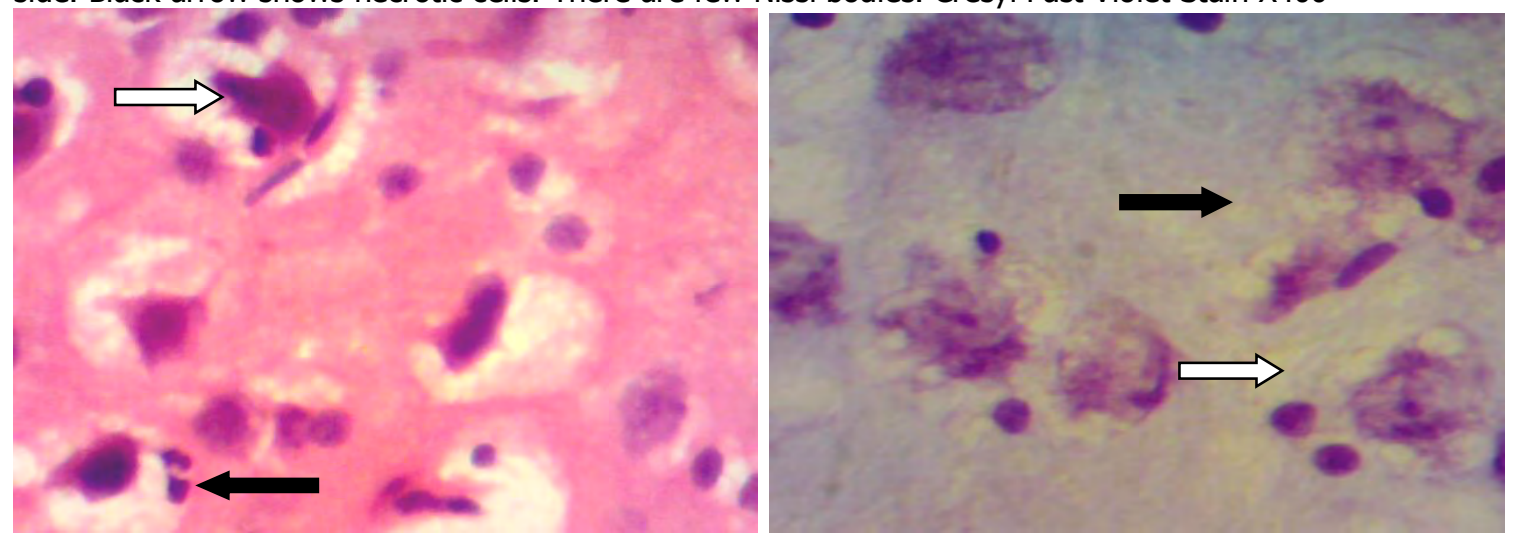

Figure 4: Group D: Photomicrograph of prefrontal cortex of group D rats. Black arrow shows cellular necrosis. White arrow shows vacuolation of neuron with nucleus not centralized. There is distortion of cortical layer. H\&E X400. Group D: Photomicrograph of group D rats. White arrow shows apoptotic cells. Black arrow shows necrosis of the cell. There is much distortion of cortical layer. Cresyl Fast Violet stain X400

Table 2 Showing Sodium dismutase (SOD), acetylcholinesterase (ACH), total protein (TP), malondialdehyde (MDA) test results

\begin{tabular}{|l|r|r|r|r|}
\hline \multicolumn{1}{|c|}{ Groups } & \multicolumn{1}{c|}{$\mathrm{MDA}\left(\mathrm{X} 10^{-6}\right)$} & \multicolumn{1}{c|}{$\mathrm{ACH}\left(\mathrm{X} 10^{-8}\right)$} & \multicolumn{1}{c|}{ SOD } & \multicolumn{1}{c|}{ TP } \\
\hline A & $6.10 \pm 2.51$ & $-14.25 \pm 14.60$ & $-1.00 \pm 1.89$ & $8.43 \pm 0.89^{*}$ \\
\hline B & $7.53 \pm 0.09$ & $1.20 \pm 47.40$ & $-1.00 \pm 1.65$ & $3.39 \pm 0.42^{*}$ \\
\hline C & $7.63 \pm 0.04$ & $-0.93 \pm 21.16$ & $-0.13 \pm 1.67$ & $2.67 \pm 0.20^{*}$ \\
\hline D & $7.76 \pm 0.10$ & $46.95 \pm 55.21$ & $0.80 \pm 0.46$ & $2.49 \pm 0.19^{*}$ \\
\hline Total & $7.23 \pm 1.36$ & $8.85 \pm 42.99$ & $-0.35 \pm 1.56$ & $4.35 \pm 2.61$ \\
\hline
\end{tabular}

*Significance at $\mathrm{p}<0.05$ 
Table 3 Showing average weights of rats, change in weights and brain

\begin{tabular}{|l|l|l|l|l|}
\hline Groups & $\begin{array}{l}\text { Initial Body } \\
\text { Weights }\end{array}$ & $\begin{array}{l}\text { Final Body } \\
\text { Weights }\end{array}$ & $\begin{array}{l}\text { Change In Weights } \\
\pm \text { Std. Deviation }\end{array}$ & Brain Weights \\
\hline A & 140.5 & 176.7 & $36.2 \pm 2.99$ & 1.55 \\
\hline B & 157.3 & 154.2 & $-3.1 \pm 1.72$ & 1.58 \\
\hline C & 166.8 & 158 & $-8.2 \pm 6.61$ & 1.55 \\
\hline D & 211 & 197.3 & $-13.7 \pm 20.99$ & 1.67 \\
\hline
\end{tabular}

\section{DISCUSSION}

The prefrontal cortex is an area of the brain in the frontal lobe of the cerebral hemispheres that is responsible for decision making, behavior and emotional control (Miller and Cohen, 2001). The prefrontal cortex corresponds to Brodmann's areas $9-12$ and $46-47$, and it undergoes functional and structural changes due to binge or chronic alcohol consumption (Abernathy et al., 2010; Brodmann, 1909). The present study shows that acute oral alcohol intake causes damage to the histoachitecture of the prefrontal cortex in a dose-dependent manner. The levels of sodium dismutase and malondialdehyde, which are two important oxidative stress markers, were shown to have increased with the increasing concentration of administered alcohol. Likewise, the activity of acetylcholinesterase increased in the treatment groups in a dose-dependent manner.

Binge drinking in adolescence and young adulthood has been shown to be associated with damage to multiple brain areas, particularly the frontal cortex and hippocampus (Bengoechea \& Gonzalo, 1990; Risher et al., 2015), as well as cognitive deficits in both human and animal studies (Duka et al., 2004; Loeber et al., 2010; Nixon \& Crews, 2002; Obernier et al., 2002; Stephens \& Duka, 2008; Stephens et al., 2005). The prefrontal cortex plays an important role in processing the subjective properties of addictive substances such as alcohol (Goldstein and Volkow, 2011). Alcohol has been shown to increase blood flow to the prefrontal cortex (Volkow et al., 1988, Sano et al., 1993, Tiihonen et al., 1994), and this effect is influenced by risk for developing alcoholism (Tolentino et al., 2011). Imaging studies in alcoholics have shown that baseline hemodynamic activity in the prefrontal cortex is substantially lower than in non-alcoholic controls. However, exposure to cues associated with alcohol experience elicits robust increases in the hemodynamic activation of this brain region (George et al., 2001, Kareken et al., 2010). Furthermore, genetic susceptibility to the development of alcoholism influences hemodynamic activation of the prefrontal cortex following acutely administered alcohol (Kareken et al., 2010). These results suggest that genetic vulnerability for developing alcoholism interacts with a history of drinking to modify, and possibly enhance, the representation of alcohol-related information. While these data highlight the prefrontal cortex as a key brain region that mediates excessive drinking, especially in those genetically vulnerable, it is not clear if, or how, alcohol changes neural firing in these populations.

Findings in this study show that the average body weights of rats in the treatment groups reduced in a dose-dependent manner. This indicates that with an increase in concentration of alcohol consumed, there is increase loss of weight. Loss of weight may be attributed to alcohol's effect on other body systems, such as the digestive system or loss of appetite in relation to the nervous system. Alcohol consumption may cause complications 
such as gastric erosions and nervous disorders (Moore, 2010).

In conclusion, acute oral alcohol intake results in distortion in the histoachitechture of the prefrontal cortex of Wistar rats in a dosedependent manner. Cerebral cortex damage due to acute oral alcohol intake is associated with oxidative stress.

\section{REFERENCES}

1. Abernathy K, Chandler LJ, Woodward JJ. 2010. Alcohol and the prefrontal cortex. Int Rev Neurobiol, 91: $289-320$

2. Ahola K. 2006. Alcohol dependence in relation to burnout among the Finnish working population. Addiction, 101:1438-1443.

3. Bengoechea O, Gonzalo LM. 1990. Effects of alcoholization on the rat hippocampus. Neurosci Lett, 123: 112-114.

4. Brodmann K 1909. Vergleichende localization slehredergrosshirnrinde in ihren prinzipie ndargestellt auf grund deszellen baues. Leipzig: Barth

5. Crews FT, Collins MA, Dlugos C, Littleton J, Wilkins L, Neafsey EJ et al. 2004. Alcoholinduced neurodegeneration: When, where and why? Alcohol Clin Exp Res, 28(2): 350-364. doi: 10.1097/01.alc.0000113416.65546.01

6. Duka T, Gentry J, Malcolm R, Ripley TL, Borlikova G, Stephens DN et al. 2004. Consequences of multiple withdrawals from alcohol. Alcohol Clin Exp Res 28(2): 233-246. doi: 10.1097/01.alc.0000113780.41701.81

7. Ellman GL, Courtney KD, Andres V jr, Featherstone RM. 1961. A new and rapid colorimetric determination of acetylcholinesterase activity. Biochem Pharmacol, 7(2): 88-95.

8. George S, Rogers RD, Duka T. 2005. The acute effect of alcohol on decision making in social drinkers. Psychopharmacology (Berl), 182:160-169.

9. Goldstein RZ, Volkow ND. 2002. Drug addiction and its underlying neurobiological basis: Neuroimaging evidence for the involvement of the frontal cortex. Am J Psychiatry, 159:1642-1652.

10. Lee K, Moller L, Hardt F. 1979. Alcohol induced brain damage and liver damage in young males. Lancet, 759.

11. Loeber S, Duka T, Welzel HM, Nakovics H, Heinz A, Mann K et al. 2010. Effects of repeated withdrawal from alcohol on recovery of cognitive impairment under abstinence and rate of relapse. Alcohol Alcohol, 45(6): 541-547. doi: 10.1093/alcalc/agq065

12. McCord JM, Fridovich I. 1969. Superoxide dismutase. An enzymic function for erythrocuprein (hemocuprein). J Biol Chem, 244(22): 6049-6055.

13. Miller EK, Cohen JD. 2001. An integrative theory of prefrontal cortex function. Annu Rev Neurosci, 24:167-202.

14. Moore SW, Griffith JA, Griffith HW. 2010. Griffith's instructions for patients. $8^{\text {th }}$ ed. Philadelphia, PA: Saunders; pp 1-448.

15. Nixon K, Crews FT. 2002. Binge ethanol exposure decreases neurogenesis in adult rat hippocampus. J Neurochem, 83(5): 1087-1093. doi: 10.1046/j.1471-4159.2002.01214.x

16. Obernier JA, White AM, Swartzwelder HS, Crews FT. 2002. Cognitive deficits and CNS damage after a 4-day binge ethanol exposure in rats. Pharmacol Biochem Behav, 72(3): 521-532. doi: http://dx.doi.org/10.1016/S0091-3057(02)00715-3

17. Risher M, Sexton HG, Risher WC, Wilson WA, Fleming RL, Madison RD et al. 2008. Cognitive and emotional consequences of binge drinking: Role of amygdala and prefrontal cortex. Philos Trans R Soc Lond Biol Sci, 363(1507): 3169-3179. doi: 10.2307/20208731

18. Sano M, Wendt PE, Wirsen A, Stenberg G, Risberg J, Ingvar DH. 1993. Acute effects of alcohol on regional cerebral blood flow in man. J. Stud. Alcohol, 1993: 54:369-376. 
19. Stephens DN, Ripley TL, Borlikova G, Schubert M, Albrecht D, Hogarth L et al. 2005. Repeated ethanol exposure and withdrawal impairs human fear conditioning and depresses long-term potentiation in rat amygdala and hippocampus. Biol Psychiatry, 58(5): 392-400.

20. Tiihonen J, Kuikka J, Hakola P, Paanila J, Airaksinen J, Eronen M et al. 1994. Acute ethanolinduced changes in cerebral blood flow. Am J Psychiatry, 151: 1505-1508.

21. Volkow ND, Mullani N, Gould L, Adler SS, Guynn RW, Overall JE et al. 1988. Effects of acute alcohol intoxication on cerebral blood flow measured with PET. Psychiatry Res, 24: 201-209.

22. Weitner T, Inić S, Jablan J, Gabričević M, Domijan A-M. 2016. Spectrophotometric Determination of Malondialdehyde in Urine Suitable for Epidemiological Studies. Croat Chem Acta, 89(1): 133-139. 